\title{
Censorship, 'Decency', and Dollars
}

Dena Shottenkirk

Hunter College

1.0 Robert Mapplethorpe, Andreas Serrano, Karen Finley, and now - Chris Olfini. They are members of a special club: the club of Those Who Offend. Let's take an example from Mr. Serrano.

Splayed with appropriate submission, the image was hidden behind a haze of blue paint and - but wait, something else was on the canvas: splattered unevenly was a spray of - well, you don't know, so you look at the title where the secret is revealed: Piss Christ. Now the reaction(s) sets in.

Reaction (1). If you are an average American, not used to viewing contemporary art, the reaction is probably: eyes widened to bulging and jaw dropping completely open and gaping, with guttural objections spewing out uninvited. Emotions of shock, anger, dismay, and repulsion sweep over this person.

Reaction (2). If you are used to looking at art and thus more jaded, the eyes slightly widen, the mouth opening a bit or not at all. The verbal response, spoken probably to oneself only, is something like: "Hmm, this is a slightly new one, wonder what the boy had in mind with this one".

Those belonging to Reaction (1) vote to lynch, or if not possible, then not to fund (a more decorum response). In response to (1)'s reaction - i.e. the general public's reaction - those belonging to Reaction (2) - i.e. the artworld - experience shock, anger, dismay and repulsion and the uninvited guttural objection of "censorship!" comes spewing out. The Greek chorus starts hooting and running amok.

The recent case with Chris Olfini is similar: there is the artworld response - the majority of whom feel benign toward the work and the more general population's response, many of whom haven't seen the work at all, yet are still appalled enough to support the House and Senate measures to cut funding. Both sets of responses are highly emotional. Both fail to see the difficult legal, political, and philosophical problems underneath the commotion. 


\section{DEFINITION}

\section{1}

It's always nice to start out with a definition. The word "censor", according to Webster's dictionary, comes from the Latin "censere" meaning to tax, value, judge. In Roman times, there were magistrates whose job it was to register the citizens for purposes of taxation and "to keep watch of the morals of the citizens, for which purpose they had the power to censure vice and immorality by inflicting a public mark of ignominy on the offender."

But a working definition is much harder to come by than a dictionary one. How do we define censorship today? Does it apply equally to any sort of expression, whether political or artistic? If we limit it to the realm of the cultural, is it when an artist is not allowed to show the work anywhere, neither in publicly funded venues nor private exhibition spaces? Or is it enough to qualify as 'censorship' when the artist is prohibited only from publicly funded venues, but is left free to exhibit in privately owned ones? In other words, is the government's refusal to fund an artist 'censorship'?

Meanings of words are notoriously slippery things, and they do (as many twentieth century philosophers have maintained) change with usage. This is not an appeal to vagueness, I assure you, but a call for reinforced rigor. I will argue that there are several different definitions of the word being circulated today, and the heated debate over the issue can be somewhat ameliorated when those uses are no longer equivocated.

\section{THEORY}

2.0 What is it that scares us about censorship? Some definition of it is, obviously, central to our notion of a democracy. We - as a society - are governed by our belief that the free exchange of ideas is the very foundation of democracy. Freedom of the press and freedom of individual expression are the legal devices which guarantee the denial of intolerance, tyranny, and violent oppression. Without freedom of the press and free individual expression we become impotent in the face of dictatorship and subject to the extremes of political cruelties which often encompass the horrors of human rights abuses such as murder, rape, and torture. 
In addition to the prevention of totalitarianism, there is also an intellectual benefit to free expression: in an atmosphere of the free exchange of ideas, it is possible to separate truth from falsehood, and for each individual to reason the best course of action for him or herself. This is straight from John Stuart Mill; it is what our constitution is based upon, and it is what most of us believe. When the expression of certain ideas is forbidden, it is because those in power deem those ideas to be infallibly wrong. But this, the argument goes, cannot be a valid criterion, because experience shows us that many ideas formerly thought to be wrong were subsequently deemed right, i.e. Galileo's proof that the world is round, Cantor's proof that there are levels of infinity, the argument that the races/ sexes deserve equal treatment. Thus, the categorizing of any idea as irredeemably wrong - and thus censored -cannot be allowed since future experience might reverse that decision. Conclusion: all ideas must be allowed to circulate, regardless of assumptions of truth or falsehood.

2.1 This is the theory, and it is underwritten by three separate arguments:

a. the harm/offense distinction, e.g. something can be illegal if it causes physical harm but cannot be made illegal if it only causes offense.

b. the legal right of free speech

c. the moral/aesthetic distinction, e.g. the philosophical claim (made more often by artworld members than by philosophers) that aesthetic decisions cannot be influenced by moral content.

One or more of these are appealed to by opponents of censorship/ non-funding. If we are to obtain a working definition(s) of censorship, and to decide whether non-funding is to be equated with censorship, we need to look at the arguments behind each of these three positions. In theory, each of these positions seem to present a clear dichotomy or definite principle; in practice none are clear. 


\subsection{The harm/offense distinction}

Theoretical Fiction. One cannot restrict expression or action which merely offends but does not harm. To harm is to a) cause physical harm e.g. assault, or b) cause harm to one's property e.g. vandalism or interfering with the practice of a business. To merely offend is just what it sounds like: I might be offended if you express opinions which are contrary to mine, such as "the races are genetically endowed with different degrees of intelligence", but that is no reason to make the expression of those opinions illegal. I don't have to listen to it; I can merely walk away or put down the book which propounds that point of view. This was the thinking of the British social philosophers, and it forms the basis of our political mores.

Empirical fact (1) As an American citizen, one is not allowed to yell racial epithets such as "nigger" without the recipient of that language being (legally) allowed to punch the speaker, without suffering the charges of assault. In other words, using what are termed "fighting words", while not illegal in and of itself, does bestow upon the recipient the right to use physical violence without being arrested and charged. Being called a racial slur is no longer merely an offense which one must suffer; it is now a harm with some degree of legal protection.

Empirical fact (2) Knowingly printing or saying false statements about a person is illegal and construed as not only offensive, but harmful as well, even though the harm is often more psychological - and thus more in the offense category - than real harm to one's physical or property rights.

Empirical fact (3) Sexual harassment also borders the line between harm and offense, for although it is often argued that it makes it impossible to continue in the job - and is thus real harm - it is often seen as objectionable simply because it so deeply humiliates and offends. In fact, many (most?) people want to see sexual harassment illegal not only when it results in a loss of employment, but also when it results in a loss of self-esteem. If a male boss whistled and hooted at his female secretary, it would not make it necessarily impossible to continue in her job, but the humiliation she suffered would be sufficient to file suit. 
Empirical fact(4) Pornography is the classic harm/offense distinction. Take the most extreme example: child pornography. The rationale for its illegality is that it does real harm to the child. But what if the image were a computer-generated one, and hence with no real victim? Would we then allow the distribution of that material? My guess is that overwhelmingly, people would vote no. The reason is offense; not harm.' This leaves aside the less pernicious cases of televised prime-time adult pornography and its restriction thereof; surely the opponents of that must admit some reliance on an offense claim, as the physical/property harm is difficult to prove.

\subsection{Free Speech}

Theoretical fiction. The rule of free speech, guaranteed by our constitution, is seen as absolute and inviolable; not subject to a continuing balancing act between freedom of expression and the (supposed) greater benefits of the society.

Empirical fact (I) The most readily available counter-example is seditious speech; we are not, according to our constitution, allowed to advocate the violent overthrow of the government.

Empirical fact (2) We are also not allowed to disingenuously yell "fire" or any other such false alarms. The good of society as a whole demands both of these constraints on free speech. It is decided, in these few instances, that the rights of the individual are worth sacrificing for the good of the whole.

Empirical fact (3) RICO - The Racketeer Influenced and Corrupt Organizations Act - was recently used in Chicago to silence a group of anti-abortion protesters. While the ACLU deplored it as an evisceration of the first amendment, abortion rights activists applauded.'

Empirical fact (4) Cigarette companies in the US have agreed to restrict their advertising in an effort to gain immunity from lawsuits by smokers. ${ }^{3}$

Empirical fact (5) Several universities (New York's CUNY among them), have denied tenure and/or employment to professors on the basis of unacceptable (e.g. racists or sexists) comments. 


\subsection{Moral/Aesthetic Distinction}

Theoretical fiction. Praise or blame for a work of art is made on aesthetic merit alone, not influenced by content or moral stance.

Fiction(s). It is de rigueur to dismiss artwork on the basis of content. Every curator, every gallery owner, every art critic does it routinely.

This fiction must be analyzed more logically than strictly empirically. But first, let us reiterate the offenses on the conservative side, for these are well-documented and empirically known. For example, the most famous U.S. case occurred in 1989 when the NEA awarded grants of $\$ 15,000.00$ to Andreas Serrano and $\$ 30,000.00$ to Robert Mapplethorpe, but as soon as the sexually explicit nature of Mapplethorpe's work and the blasphemous nature of Serrano's became known to certain members of Congress, a furor arose. But the legal issue came from a suit filed by Karen Finley, Tim Miller, Holly Hughes and John Fleck, after grants to them were rescinded as a result of congressional objections to the work. ${ }^{4}$

The June 1998 Supreme Court ruling will be discussed later, but for present purposes the following question is posed: we know "viewpoint discrimination" (the Court's words) cuts that way: but does it cut the other way also? In other words, does the NEA fund work - or museums and galleries exhibit work - that is racist, or sexist, or work that promotes, say, genocide or sexual abuse of children? Do we have, say, 1930s artwork exhibited which depicts Jews as dirty and deformed? Or artwork from earlier in the century that shows blacks as stupid and animal-like? Do we see artwork made by skinheads or white supremacists? What's happened, in this day of animal rights, to those lovely scenes of fox hunts or elephant trophies? Does this mean that all, absolutely $100 \%$, of that work has no redeeming artistic merit? I have never seen any such images on display, and it seems logically impossible - logically impossible, given the facts of probability - that this is the result of an "aesthetic" decision alone.

The difficulty here is that this sort of censorship (or perhaps it would merely be called "editing") is done away from the light of public scrutiny. Refusal to fund or exhibit remains internal to the institution which invites neither public approval nor disapproval. 
The inherently private nature of such discussions, which take place in a room with closed doors among a small group of like-minded colleagues, is not conducted in an atmosphere of secrecy as much as in an atmosphere of mutual agreement. The "appalling" is generally not debated; there are few white supremacists or anti-Semites in the group, making tacit dismissal of the errant artist rather easy. If the slides of an artist whose work conveyed less than acceptable attitudes toward race (or even gender - although a less vociferously defended stance) were displayed to those NEA members on the panel, it is inconceivable that negative comments would not erupt, and that those comments be universally agreed with. And it is even more than inconceivable that they would, despite the content of the work, choose to fund that artist. The inconceivability is demonstrated by the fact that such work is, in fact, not funded. I have never seen images that portrayed blacks or other minorities in a blatantly insulting way, or images that promoted slavery, or images that justified the Holocaust. And knowing the enormous variety of work that is done in the world, it is, probabilistically, unbelievable that such work does not ever come across the table, and that occasionally such work is otherwise skillful and formally inventive enough to justify the support of a grant. Refusal on the basis of content simply must be inferred from the fact of the absence of work which offends the majority "correct" view.

2.5 And what does all this amount to? The three general principles which support arguments against censorship and against a refusal to fund - the harm/offense distinction, freedom of speech, and the moral/aesthetic distinction - each admit of exceptions significant enough to demonstrate that the principles are not inviolate. But while not inviolate, the principles only admit of exceptions when the cost is too high for society relative to the cost to the individual. To repeat a previously cited example, the few exceptions to free speech which are tolerated in the constitution or laws i.e. such as sedition and falsely yelling "fire", are those whose performance we deem intolerably and unproductively destructive of the social fabric. The point here is that each exception is looked at singly, in its consequences to both society and to individual freedom. As individuals, we lose very little by not being able to falsely yell "fire", 
but as a society we lose very much if it is allowed. We draw the line with each of them contextually, adjusting the absolute demands of the principle to the needs of social cohesion. The point here is obvious: the question is not whether or not it is ev'er done, but rather which exceptions are tolerated. This is a gray scale that must be accommodated instance by instance. For example, almost all of us (I'm sure there are a few crackpots out there somewhere who disagree) agree that we don't want speech which advocates the violent overthrow of the government, but are we in that much agreement about banning cigarette advertising or abortion clinic protesters? With the recent rulings against such defendants, many civil libertarians see us descending a slippery slope that predictably ends with a substantial disemboweling of the first amendment.

Is the refusal to fund offensive art of the same category?

\section{LEGAL RULINGS}

\subsection{U.S.}

The Supreme Court's decision in Karen Finley's case involved a ruling on a 1990 law requiring a 'decency test' by the NEA in their awarding of grants to artists. The Court decided (in a majority ruling written by Sandra Day O'Connor) that such a requirement was advisory only, not therefore actually forbidding such grants to individuals not meeting the 'decency' requirement. In other words, the law does not constitute viewpoint discrimination, and is therefore constitutional.

The majority decision was complicated, though, by the dissent of two members (Scalia and Thomas) who argued that the law did constitute viewpoint discrimination, but that because it was in the area of disbursement of Federal subsidies, that viewpoint discrimination did not violate free speech rights, and was therefore constitutional.

The lone minority dissenter was Justice Souter, who, while agreeing with Scalia and Thomas that it was viewpoint discrimination, disagreed with their assessment that it was okay. For Souter, the statute is unconstitutional because "The decency and respect proviso mandates viewpoint-based decisions in the disbursement of Government subsidies, and the Government has wholly failed to explain why the statute should be afforded an exemption from 
the fundamental rule of the First Amendment that viewpoint discrimination in the exercise of public authority of expressive activity is unconstitutional."s

It is important to be clear about the differences among the justices. There are three positions being lined out in this 8 to 1 vote upholding the statutes' constitutionality:

1. O'Connor for the majority: because the ruling is advisory only, it is not viewpoint discrimination. Therefore, OK.

2. Scalia \& Thomas - dissenting opinions in the majority vote: while the law does constitute viewpoint discrimination, it is only within the realm of federal subsidies, and not therefore encroaching into the realm of free speech issues. To give money or not to give money in support of something is unrelated to forbidding something entirely. Therefore, OK.

3. Souter for the minority: it is viewpoint discrimination and no one has shown that disbursement of federal funds is separate from other instances of governmental "exercise of public authority". Therefore, not OK.

I have gone into detail on this ruling because the opinions of the justices very clearly lay out the lines of the debate: is funding like other "exercise(s) of public authority"? In other words, does a government decision to fund or not to fund have the same status as other legal rulings? Does non-funding = censorship?

\section{1}

\section{INTERNATIONAL LAW}

The United Nations has no special category for censorship in the arts. When a journalist or writer or artist is suppressed by a government, it is generally in the form of physical imprisonment, torture, or murder. This is censorship in its most literal and extreme form. United Nations documents such cases as instances of violations of human rights, and not as extreme cases of censorship: - there is no compilation of art censorship instances and hence, no category, internationally, of censorship against the arts. 
The intergovernmental organization WIPO - the World Intellectual Property Organization -headquartered in Geneva, held a convention on March 2, 1997, and continued the amending of the 1886 Berne Convention for the Protection of Literary and Artistic Works. Both Canada and the U.S. were signers to this agreement, which provided three basic principles determining the minimum protection to be granted artworks, including "the right to communicate to the public the performance of such works". 6

Non-funding, while failing to provide the financial support to produce work, does not prevent the "right to communicate to the public the performance of such work". Not paying an artist to make the work does not, in logical terms, absolutely prevent the artist from doing so. It might, in practice, make it more difficult for the artist to get the funds necessary to make the art, but it does not in fact prevent him or her from doing so.

Therefore, a particular government's decision to not fund does not run amok of international rules on intellectual property rights.

\section{0}

\section{ALTERNATE VIEWPOINTS}

What do we do with viewpoints which are radically different from our own?

Creationists e.g. those disagreeing with Darwinian evolution and taking instead a literal translation of the Bible - are currently arguing that their viewpoint should be presented in the public schools along side those of the scientific account of evolution, and advocate laws requiring tax payers dollars to implement that.

The geologist Donald E. Wise ${ }^{7}$ has pointed out some incompatibilities in these theories that would make teaching them as relativist alternatives impossible. For example, the 4.5 billion-yearold geologic time scale that all the sciences use, is not believed by the creationists, who compress the history of the universe into about 6,000 years. Thus the creationist explains the fossil record of the earth as having been deposited during the year of Noah's arc. In addition to these problems, the Bible's story of creation has some events occurring in reverse order from an evolutionary explanation i.e. birds before land reptiles (biologists reverse that order), fish before insects (the evidence has insects before fish), etc. The 
funding of both of these viewpoints is illogical: one must be right. Which should our money go to, and: is the loser being censored?

This is perfectly analogous to Karen Finley's case. If we choose not to fund the creationists e.g. to pay them to present their case, we are then doing the same thing as choosing not to fund Karen Finley e.g. to pay her to present her case. Is it censoring: is it preventing the creationists from having their public forum? Clearly, (most would say) they can print their material at their own cost or hold public lectures in places that aren't paid for by the government. Does this limit their audience? Certainly. But since the majority of the U.S. population is not interested in hearing their viewpoint, that limitation is only reasonable.

The only way that government refusal to fund or support would be equivalent to absolute censoring, would be if the government controlled all access to printing presses and public meetings. This was the situation in Stalinist Russia, in Nazi Germany, and in several other countries such as today's Iraq. (It is more marginally true in places like China, where government control is almost complete and repression still difficult to successfully challenge.) What I'm putting forth here is the merely logical point that not-funding is absolute censorship if and only if the government's control is absolute, leaving no room for private recourse to funding or public expression. Is it censorship of another kind, though? This is where the equivocation of terms arises.

4.1 Three possible definitions of censorship have emerged, which I will define as $\mathrm{Cl}, \mathrm{C} 2, \& \mathrm{C} 3$ :

"C1": one is allowed to make the art, but not exhibit it anywhere. This is a situation one can imagine happening in a country where all venues for exhibition or publication are owned or controlled by the government, and yet there are legal protections in place that forbid outright persecution for privately practiced artistic endeavors, or through governmental apathy, the making is not suppressed. The exhibition would be censored, but not the making.

"C2": one is allowed to make the art, but cannot exhibit the work in government sponsored places - but still exhibit it in other e.g. private venues. This is a situation that (potentially) 
obtains now in the U.S. along with many other countries. Since most of these are liberal democracies with capitalist economies, private opportunities outweigh public ones.

"C3": one is allowed to make the art but it is refused private exhibition opportunities because the content of the art is offensive to the vast, vast majority of people, including the curator making the decision. For example, if an unassayed image of a shabbily dressed black man in clear servitude to a white person ${ }^{8}$ were refused exhibition in a show, and the curator was honest and self-aware enough to admit that it was in some measure the content which was the determining factor, would this be censorship?

4.2 The definition $\mathrm{Cl}$ would certainly be considered censorship by most people. It is completely restricting the exhibition of the work. C3 - even in the improbable event that it came to public's attention - might not be considered censorship, although the curator might be accused by some of moralizing. What about C2? This is the nub of contention.

\subsection{TO OFFEND}

Like Alexander the Great's creative initiative, let's do a flank attack. Let's attack the question from the other direction: what does it mean to qualify as offensive? Is it to be offensive to the almost all of the population, the majority of the population, or merely some sub-group of the population? And what is it called when it merely offends one person? Or when it offends most people?

To take an arbitrary example from the other side of the majority-opinion divide: a photograph of a fully clothed woman, dressed in a long skirt with long sleeves, but with the skirt slightly lifted on one side so that a bare ankle is showing. A man - say, an Islamic fundamentalist - claims this is offensive. What do we say? We would probably say, "no, you are offended, but that does not mean the picture itself is offensive." The art then is not offensive, and it is this tiny minority of the offended whom are merely judging wrongly. Political, social, ethical arguments are given, and this minority, being a small and politically ineffectual minority (in this country), thereby remains an ineffectual minority, and the photograph remains hanging. 
But when does the offense switch from the "misjudgment" of one (or two, or a handful) to being deemed a plausible and reasonable position? In other words, when does it go from a crackpot position to being a respectable minority to being the norm? To frame the question philosophically, when does the property of "offensiveness" come to be placed not within the mental acumen of the viewer, i.e. an epistemological issue, and placed instead within the object itself i.e. an ontological issue?"

5.1 For at some point, we decide the offense lies not within the mistaken view of the beholder, but within the object itself: the object is offensive. Is it when it crosses that magical $50 \%$ line - then it shifts from 'opinion' to 'fact'? Or is it enough that a viable minority believe it? Surely, if only one person thinks an image offensive, the rest of the society calls the opinion "mistaken" or "crackpot" or something of the sort. If I believe that the image of an apple is obscene, my position won't be taken very seriously. Conversely, if only one (or a few) people champion an image which the rest of us maintain seriously violates basic rules of social behavior as would, say, a film promoting genocide, or the photograph promoting child pornography, we balk. We must not deny this process: there are many things which we would all agree were offensive, and only those whose opinions remain unexamined by themselves hold this to be untrue. Glorification of the Nazis, child pornography, snuf films (where one witnesses the actual murder of a person, done for the said purposes of making the movie), white supremacy, etc., etc. Any discussion of the issue of censorship without the recognition of this fact will necessarily result in the banal whining of the those who are "against it" and those who are "for it", and the "odor of mendacity" (to quote Big Daddy) permeates such discussions ad nauseam. The politically incorrect fact is that there are many things we identify as cultural norms e.g. opposition to slavery, etc., for which we allow almost no exceptions. We are not as much of a relativist society as we would like to think. We all exercise censorship, even that nasty kind based on content. This is what has to be looked at, without milksop aversion or rhetorical denial. 


\subsection{TRIAGE}

If you go to an emergency room there is often a sign up that says "triage": that is, which degree of emergency - extreme, moderate, or can-wait. I would like to borrow a classificatory distinction, which is something along these medical lines, made by the philosopher David H. Sanford in as essay on causation, " where he makes distinctions between the kinds of views which will be described: "prevailing, majority, or controversial.... There will be no discussion of cogent objections to prevailing views." Perhaps this is the way it works with censorship: prevailing views - those held by the vast majority of people i.e. opposition to slavery - are readily reiterated. Majority views - those with slightly more than $50 \%$ of the population are also listened to i.e. abortion rights arguments. Controversial (or minority views) - those somewhat less that the $50 \%$ i.e. anti-abortionists - are listened to, entertained, and allowed. But not so with cogent (sic) arguments against the prevailing views. We do not broadcast, print, fund, or otherwise entertain those points of views. We do not discuss arguments for slavery. These are just called crackpot and dismissed. Unfair? Read on.

For example, arguments justifying murder or rape are "censored" (this is the C3 definition of censorship), by which I mean, simply not published; people simply do not want to read them. If submitted to a publication, they are not seriously considered. I have witnessed meetings where 'ridiculous' things were dismissed out of hand, and have heard of other instances second-hand. On a logical note, one never reads such a thing, and knowing the infinite possibilities of human mind, one can certainly assume that such things have been written from time to time and submitted. Oh - de Sade. Perhaps an exception (stylized into fashion, though it is) exists. Nevertheless, as a rule it seems to hold - positions which argue for unrestrained rape or murder - for the destruction of the social fabric - are not given much public credence. The Bloods will never be allowed to present their arguments for maiming and murder in a podium next to Mother Teresa's arguments for charity; equal time will not be given to all.

6.1 The "criminal" is a category for the simple reason that some things, if allow'ed, will spell the end of all other things. This often 
falls within the category of "There will be no discussion of cogent objections to prevailing views." This is, in fact, how it tacitly works all the time. We don't argue about those things which we have already agreed upon. Such positions are exactly what Prof. Sanford is referring to with that phrase. Mill missed this point, and it's an important one. Not every single issue is continuously up for grabs. Even though many of these issues will not be prosecuted (unlike disingenuously yelling "fire"), many of them will, nonetheless, merely be ignored. This means: not published, not exhibited, not taken seriously. Is this censorship? It would be to John Stuart Mill, but it probably is not to most of us. (That's a recursive justification, there!)

6.2 What then happens to artists who are refused federal funding and exhibition in federally funded spaces? It might be championing the obvious to say that artists are emulous of other artists' public recognition, but it's important to point out that the artists who are refused funding because their work is deemed offensive certainly fair no worse; being banned by the government has not been damaging for the reputations or financial gains of those the government hailed as evil. Andre Serrano's earnings went from negligible to one of the most financially successful artists of the Paula Cooper Gallery (sought after particularly by European collectors), a gallery which is itself one of the most successful galleries in NY; and Robert Mapplethorpe, while not a complete unknown beforehand, is now protectively embanked within the walls of the aesthetically sanctified. Karen Finley's reputation soared while the case was awaiting trail, and as she was coincidentally performing her 'controversial' piece "The Return of the Chocolate-Smeared Woman" in NYC during the period when the case was being decided, it was interesting to see the results. New York's The Daily New's headlines the article: "Her successful chocolate-smear tactics. Say this for the U.S. Supreme Court: It's great for the box office" Her show was a near sell-out and was extended for a week.

The vibrant realm of exhibition spaces in the U.S. is not the government-financed world, but the private world of galleries and collectors. That is where the money is and that is where the power 
is. The NEA, however public its profile, is a mere drop in the cultural bucket. Being refused by the NEA (or, more accurately, by the conservative forces in the government) is really very much like being "banned in Boston": the public only wants it more. Being refused federal funding is more like being guaranteed private success, with usually a lot of money trailing along behind.

6.3 And so, the other fork of the question: what damage does such refusal to fund do to us, the public? That is a thornier question: to what extent do we suffer when our government denies some (that is, publicly funded) access to debatable topics? Going back to the triage division between prevailing, majority, and controversial, much of these artworks qualify as contrary to the prevailing opinion to the general public, although not so to the artworld, where standards have been pried loose and are more tolerant of differences. Think back to the original characterization(s) to Serrano's Piss Christ: the artworld reaction was not isomorphic to the nonartworld one. To the artworld, S\&M imagery and (semi) sacriligious artworks are controversial, at most. More likely, they don't generate a lifted eyebrow. There is a bifurcation of standards here, and thus a bifurcation of tolerated artworks.

There is usually not this bifurcation of standards. Most of the general public (those in small towns in the Midwest, for example) would not want to see the racist photograph cited earlier funded by the government and exhibited, nor would most of the artworld want to see it exhibited or funded. Both groups would also agree on not funding Hutu writings that argue for the extermination of the Tutsi (imagining that it presented itself as art), nor would people want art that espoused the virtues of slavery. Those examples are contrary to the prevailing opinions, and people have no real qualms in refusing them, even if the word censorship never comes to their edited consciousness.

But Serrano, Mapplethorpe, etc. really belong more in the "controversial" or "majority" category for most of the artworld (e.g., it's not an absolute shocker, guaranteed to destroy all social interactions), although they do not belong in either of those categories for most of the general public. Here is the real problem. For many in the general public, Serrano and Mapplethorpe are solidly in the 
camp which is contrary to the prevailing opinion, not unlike arguments for rape and murder.

6.4 Here then is the hard nut: I have argued that we really do agree - whether we admit it publicly or not - that a category such as "prevailing opinions" does and should exist, and that opinions contrary to it are not really "up for discussion". What we, as a society, disagree about is where to draw the line. We have a structure within the government which is supposed to be answerable to the general public -as are all government structures within a democracy - and yet this particular one, the one which funds the arts - has a split loyalty also to the art community, which is esthetically (and ultimately, morally) not co-extensive with the general public. Which sides' standards should prevail?

\section{DEFINITIONS, AGAIN}

7.0 Again, the question is not one of "do we censor?" or "do we not?": that is disingenuous and fatal to real discussion. We do "censor", at least in the C3 definition: we do it all the time. It is not what Mill wanted, but it is a real fact of social cohesion. The distinction between harm and offense is merely fatuous, as is the moral/ aesthetic one. We do not fund the portrayal of violently racist, genocidal, pro-rape, or child pornography images. Increasingly prohibited i.e. socially unacceptable, are images portraying animal cruelty, or cultural and/or religious chauvinism. "Society" e.g. an increasing and overwhelming majority, agrees that certain things are harmful to the fabric of peaceful cohesion, and quietly shelves them. They are simply not presented. And named or not, that is some version of censorship, although certainly not the $\mathrm{Cl}$ variety. Certainly not the definition of 'censorship' that is referred to when people decry it.

This is, then, the equivocation. People are in fact referring to an event defined accurately as a $\mathrm{C} 2$ or even $\mathrm{C} 3$, but accusing the perps of $\mathrm{Cl}$.

7.1 Does the non-funding of Serrano and Mapplethorpe fall within the $\mathrm{Cl}$ category? No one would really say so. Most people would admit that it is clearly a case of C2, but - like the Supreme Court 
justices - would be unable to decide if therefore it was a restriction of the First Amendment. More precisely, whether or not (as Souter correctly points out) funding decisions are like other examples of "public authority". This is the real issue the government and courts have failed to decide. Is funding, as Justice O'Connor put it, "when the Government is acting as a patron rather than as a sovereign", 12 thereby making funding decisions not like other acts of authority? But leaving that legal issue aside, were these artists' rights to express themselves limited by the government's decision not to fund them?

Since their fame increased in inverse ratio to their castigation by the government, I don't think so, but this is not completely a discussion for logic. This is also about the voting power of democracy, its "tyranny", if you will. When the vote is overwhelmingly in the majority (say 99\%), those in disagreement are viewed as beyond comprehension. Crackpots, crazies, disenfranchised. While we all grant that each of those people have a legal right to express themselves, we are also in agreement that government funding should not support that expression. Nobody wants to pay for a pro-slavery argument to be presented in the schools, or on public television.

But when the numbers shift a little, the crackpot becomes a tiny minority and the opinion is taken slightly more seriously. They are extremists, but they gain a little audience. The white supremacist movement in this country has gained some audience, as has the anti-tax movement. The S\&M adherents, formerly of this fringe club, have recently moved more mainstream thanks to fashion, movies, and some art. In some cases, such as public debates, one can image government money paying such groups to present their case. This is the point at which you look at the effects on the minorities within the culture; one of the real reasons for the creation of democracy in the first place. The views of one or two crackpots are not seriously defended (will you listen to arguments defending slavery?), but the arguments of a minority are. This is simply numerical. The problem becomes: How does one retain some equipoise in the battle between the rights of the minorities and the cultural mechanism which rules some very few things as beyond the pale of discussion? What is the number we must cross in order to 
go from disenfranchised loonies to embattled minority? The battle line between the two is thin and ferociously fought, but the fight is a political battle, not a theoretical one. It is not a battle over whether or not 'censorship' of any variety exists, but when. We simply don't call it censorship when it is only a few crazies; we do call it so when it is a minority.

The NEA battle over art censorship was presented in the falsely binary terms of: Does or does not a government agency have the right to refuse exhibition funding on the basis of content? This obscured the fact that government (and non-government) agencies do in fact refuse art on the basis of content, although never calling that overwhelmingly-agreed-upon-decision 'censorship'. In other words, this falsely black/white battle also obscured the tacit triage of opinions which I have laid out: none of us are interested in positions contrary to prevailing opinion. In other words, I have argued that in fact there is always a C3 kind of 'censorship'. The only point is that we - the artworld and the larger society - generally agree. What we don't agree about is this particular instance, which is how it gets upgraded to a $\mathrm{C} 2$ position. That is a radically different point.

But: is not being funded the "mark of ignominy" that censorship is supposed to be? There is a term, I believe, which defines this: "positive scandal". It is good to look bad; if the conservative government thinks you're naughty, it is like the seal of approval to all those collectors who desire to buy their way into a forbidden land of unrestrained lust and carelessly broken rules. Without the parental finger-wagging by the government, that Shangra-la would disappear. So, the collectors get their thrills, the artists get their money and increased opportunities to make their work. It all works so well... I know the Supreme Court is not the same as a PR firm, but...

The more recent situation involving the Brooklyn Museum is slightly different, for that begs the question whether or not a museum could show work that offended no one. I suspect that even if the entire museum's exhibition schedule offended no specific special interest group, its blandness alone would offend some. In short, offense - in some measure - is an inherent part of any exhibition 
or discussion. If the standard for funding a museum is that it offends no one, ever, then no museum could be funded, period.

\subsection{RESOLUTIONS}

There are only two ways this political situation can be resolved, neither of which are desirable.

1. The NEA can be responsive to the standards of the art community only, and ignore the standards of the larger U.S. population. Although this would resolve the problem of a funding agency being answerable to competing and mutually exclusive demands, it would set a dangerous precedent for other minority demands, for the artworld must be seen as a minority, at least in terms of voting patterns. Creationists, white supremacist, etc. would also not be held accountable to the greater majority vote, and could logically demand support for their causes from a sympathetic government office. What if the National Endowment for the Humanities was run by some ultra right-wing people who were primarily aligned to such groups, and saw their constituency as those groups? What would stop them from those excesses, given that precedent?

Or to take a plausible sort-of Jurassic Park fiction: a group of scientists are using government funding to re-create, from found DNA, recent additions to the fossil record such as woolly mammoths and Saber-tooth tigers. Though the general public thought this ill-advised and vehemently opposed it, the scientists exerted their rights, ignored the majority consensus, and insisted that the funding continue. The voice of the majority of the population would not be heeded since the funding source was responsive only to the needs of the (minority) scientists.

In other words, to make a general precedent which by-passes the political pulse of the majority could have disastrous consequences. Majorities aren't always right, but as a rule, they are more often right than the sum of the instances when various minorities are right. Democracy is based on this math.

2. The other possible resolution is a cultural one. The essential problem is that the standards of the artworld and the standards of the U.S. as a whole are not isomorphic. This is partly the function of the avant-garde in art: the engine of invention takes a while to trickle down to the rest of the populace. For example, Cubism is 
probably liked by many of the conservatives in Congress, as might be Surrealism or Impressionism. Some of them may even be so daring to have caught up with 1950s abstraction. But they are certainly not in step with the current scene.

And if they were, what would it mean? If the whole country shared the same aesthetic as the artworld and hence would not balk at funding any art, what would that mean for the identity and role of the artist? No longer the leaders at the cutting edge of the radical, the artist would engender the appeal of an everyday KMart purchase. The salon would be back, approved of by all. Is this what anybody wants?

This dissonance of standards between the general public and the artworld needs to be in place if the artworld is to continue its role as avant-garde innovator. For if Oprah could explain it to a receptive and approving audience, we'd all be in trouble.

\section{NOTES}

1. A ruling is expected soon by the United States Court of Appeals in San Francisco on a case involving a state amendment to the child pornography laws prohibiting the possession of computer-generated sexual images of children. This is the first such case to go to court.

2. Lewis, Neil A. "Switching Sides on Free Speech", New York Times, July 1998.

3. Ibid.

4. Greenhouse, Linda. "Justices Uphold Decency Test in Awarding Arts Grants, Backing Subjective Judgments", New' York Times, June 26, 1998.

5. Ibid.

6. WIPO General Information, 1997. WIPO Publication No.: 400(3) * ISBN 92-805-0238-7, pg. 63.

7. Wise, Donald E. "Creationism's Geologic Time Scale", American Scientist, March-April 1998, pp. 160-173.

8. This following sexist image (my initial choice for the example) would not be as readily dismissed as a racist one; hence my use of the race image. Example: a photograph of an eroticized and 
naked pubescent girl shown licking the shoes of a middle-aged man who is holding a whip and a dildo. That one might actually go over fine.

9. This is like a sorites.

10. Sanford, David H., "causation" in A Companion to Metaphysics Ed. by Jaegwon Kim and Ernest Sosa; (Blackwell Publishing, Cambridge, Mass. 1995); p. 79.

11. Sutton, Larry, "Her Successful Chocolate-smear Tactics", New' York Daily News, June 28, 1998.

12. Greenhouse, Linda. "Justices Uphold Decency Test in Awarding Arts Grants, Backing Subjective Judgments", New' York Times, June 26, 1998. 